\title{
Szkic stanowiący wstęp do badań o Państwie wiedzy
}

\author{
François CHÂTELET ${ }^{1}$
}

\section{KEYWORDS}

state; power; society

ACKNOWLEDGEMENT / ŹRÓDŁO PRZEKŁADU

Châtelet, F. (2007). Brouillon pour une introduction à l'étude de l'État savant. Cabiers critiques de philosophie, 4, 163-181. $1^{\text {st }}$ ed.: Cazenave, A. \& Lyotard, J. F. (Ed.). (1985). Mélanges Gandillac. L'art des confins. Paris: PUF.

${ }^{1}$ François Châtelet (1925-1985), francuski historyk filozofii, współzałożyciel Departamentu Filozofii Uniwersytetu Vincennes. Autor prac poświęconych Platonowi, Heglowi, filozofii politycznej. 
W dobrym tonie jest dziś obwinianie racjonalności, którą uznaje się za przyczynę wszelkiego zła przytłaczającego współczesne społeczeństwa, przemocy ze strony państwa wobec szerzenia się braku kultury, świata koncentrującego się na niszczeniu zasobów naturalnych, indywidualnej alienacji względem zbiorowej rezygnacji. Nie chodzi tu o odrzucenie takiego poglądu, o odrzucenie, które na tych kilku stronach sprowadziłoby się do przeciwstawienia zbytnim uproszczeniom innych uproszczeń, nie mniej nadmiernych. Nie chodzi też o opowiedzenie się za rozumem oraz o wychwalanie cnót tego odwiecznego boga, ponieważ formułuje się wobec niego zarzuty i przybiera na sile wrzawa, która zewsząd domaga się uzupełnienia duszy. Chodzi tu o pewną spekulację, to znaczy działanie dziennikarskie, ponieważ okazuje się, że dziennikarstwo idei stało się głównym miejscem rozkwitu słowotoku metafizycznego. Zresztą cóż znaczą te dyskusje i ta gigantomachia, gdzie w zaskakującym zgiełku ścierają się wielkie koncepcje świata, „punkty zwrotne historii”, Prawo, Autorytety oraz Konstrukcje, gdzie natarczywi oskarżyciele będą szukać w przeszłości, mniej lub bardziej odległej, przykładnych winnych, chyba że zaściankowi obrońcy nie sięgną po rehabilitację nieszczęsnych, niesłusznie skazanych myślicieli.

Cóż znaczą te parodie? Z końcem drugiej wojny światowej oraz w dekadzie, która poprzedziła jej wybuch, powstał kompleksowy i wielowymiarowy system, którego techniki wypróbowano tu i ówdzie: w Stanach Zjednoczonych, w nazistowskich Niemczech oraz w Związku Radzieckim, a w trakcie samej wojny traktowanie ludzkiego materiału zapewniło jego rozwój. Gwarantuje on ogólną i szczegółową regulację wszystkiego, co powstaje i krąży po planecie, kobiet, mężczyzn, dzieci, zawodów, pieniędzy, wielkich i małych urządzeń, zaopatrzenia, gadżetów, słów, zapisów, opinii, symboli itd. Otóż faktem jest, że - paradoksalnie - owo zawładnięcie, którego operacyjny charakter nie mógłby być podważony, a które wykorzystują różnorakie instytucje ze względu na swoją strukturę narodową, międzynarodową czy światową i które za wyraźne cele stawia sobie nie tylko bezinteresowną wiedzę, ale także dobrobyt i bezpieczeństwo grup, nad którymi sprawuje kontrolę, poprawę warunków życia, utrzymanie równowagi sił planetarnych, walkę z przeludnieniem oraz zacofaniem, kończy się niepowodzeniem tego przedsięwzięcia. Czy to jego działanie jest, można by powiedzieć, wewnętrzne, czy też istnieje coś na kształt rozbieżności między celem, który sobie wyznacza, który opanowuje raczej poprawnie, a sektorem rzeczywistości, który ten cel chciałby wiernie odzwierciedlić, i czy w związku z tym myli się najczęściej w swoich przepowiedniach, nawet krótkoterminowych; czy też we wszystkich dziedzinach pojawiają się „kryzysy”, które nadchodzą nieprzerwanie, aby udaremnić wyliczenia, których te instytucje mogły dokonać i być może zastosować je, gdyby dysponowały one jakąś władzą, pośrednią lub bezpośrednią; czy wobec tego, zawładnięcie i faktyczne podporządkowanie, które ewentualnie z niego wynika, co zdarza się coraz częściej, czy to dlatego, że działają one, stosując represję, podburzanie, kontrolę, prowokację 
lub jakąś inną metodę, którą można sobie wyobrazić, i udaje im się zwykle tylko w niewielkim stopniu zracjonalizować życie społeczne, czy też dlatego, że napotykają one bez przerwy trudności, „odchylenia”, jak mawiają ekonomiści, które wchodzą z pewnością w dalszej kolejności w wyliczenia, ale po fakcie (i po poniesieniu kosztów). W każdym razie jest zbyt oczywiste, aby to podkreślać, ale nigdy, od kiedy Państwa narodowe zapragnęły stać się Państwami wiedzy, światowe konflikty pojawiające się we wszystkich dziedzinach nie były aż tak liczne: wojny międzynarodowe oraz domowe, kryzysy ekonomiczne, konflikty oraz nadużycia i wszelkiego rodzaju zanieczyszczenia środowiska, przestępczość, kryzysy demograficzne, przemoc ze strony rządzących, nierówny poziom życia. Rozwój informacji nie jest jedyną kwestią, którą należałoby przy okazji poruszyć. Wszystko dzieje się tak, jakby to, co nieprzewidywalne, rywalizowało pospiesznie z tym, co przewidywalne, i jakby przypadki usiłowały ośmieszyć byt.

Czy to oznacza, że te naukowe instytucje i organy władzy wykonujące swoje dyrektywy są nieskuteczne? Codzienne doświadczenie w krajach uprzemysłowionych, liczne skargi i wzajemne oskarżenia podnoszone z każdej strony przeciwko ingerowaniu w życie osobiste jednostki społecznej: zawodowe, sąsiedzkie, rodzinne, indywidualne poprzez regulację państwową, nadmiar literatury socjologicznej poświęconej badaniu roli miejsca, jakie zajmuje w naszych społeczeństwach sieć techno-biurokratyczna, pokazują, że ogólnie nieskuteczne, biorąc pod uwagę cele, jakie sobie stawia, zarządzanie ludźmi jest jednak coraz bardziej stanowcze. Wzrost tak zwanego sektora usługowego oraz, wewnątrz niego, liczby przedstawicieli władzy centralnej, odpowiedzialnych za ustanowienie i wdrożenie rozporządzeń, które kierują życiem i śmiercią, zdrowiem i chorobą, pracą i wypoczynkiem, płacą i ubóstwem, zyskiem i stratą, jest ciągły. Obciążenia regulacyjne są wszędzie: poddajemy się im i skarżymy się na nie. Skarżymy się na nie, ponieważ w każdej chwili wolna wola w każdym swoim najmniejszym działaniu — jest udaremniana, ponieważ przyszłość jawi się jako powtórka teraźniejszości; ponieważ śmierć przejmuje władzę nad żyjącym, gdy tylko zdąży się ono pojawić; ponieważ, nieuchronnie, te liczne rozporządzenia zaczynają przeczyć jedne drugim i ponieważ niemożliwe jest ich zniknięcie, rodzą się trudności, których rozwiązanie empiryczne pożera pojedyncze istnienie. Jak mawiał Franz Kafka, oficjalny dokument z ministerstwa nie tylko dławi pragnienie rewolucyjne, ale jeszcze doprowadza do obłędu. Prawdą jest, że psychiatria zajmująca się tym problemem z pewnością udoskonali regulamin nakazujący wprowadzenie do użytku tej nieszczęsnej sytuacji...

"Glina” nie mieszka w naszych głowach. Jest on codziennie w skrzynce na listy; jest na rogu każdej ulicy, w mundurze lub bez niego; jest w kamerze nagrywającej poranne przyjście pracowników w głównym holu siedziby banku. Poddajemy się temu, ponieważ przestrzeń i czas są reglamentowane i stanowią warunek a priori życia społecznego, to znaczy po prostu życia. Do Państwa prawa doszło jeszcze Państwo reglamentacyjne, które się czasami zamieniają, o czym 
świadczą, każde na swój sposób, społeczeństwa wielonarodowe lub codzienna rzeczywistość tak zwanych krajów socjalistycznych. W każdym razie, między powszechnym nakazem praw a okolicznościowym i technicznym dowództwem „małego wodza” posiadającego umowny autorytet, wdrażane są pragmatyczne deklaracje pojawiające się po to, ażeby regulować w sposób niezwykle staranny postępowanie jednostek oraz grup.

Powstaje zatem sprzeczna sytuacja: siła - Rozum, jak się powie, który działa poprzez sprawowanie władzy lub którego władza używa jako najbardziej odpowiedniego instrumentu, ponosi porażkę na pewnym poziomie, a zwycięża na innym; dokładniej mówiąc, dostrzeże się z łatwością, iż pod wieloma względami Rozum jest aktywny i zwycięski i że przewodzi „tak naprawdę" światu, ale że działanie to daje rezultaty, które przeczą zamiarom odpowiadającym charakterowi tej siły. Obwinia się „najlepszy ze światów, który jest u naszych drzwi”, i tych, którzy dążą do ustanowienia go, gdy tymczasem mnożą się konflikty i gdy intensywniej niż kiedykolwiek trwa wyścig szczurów. Zrozumiałe jest, że proste i bardziej skłonne do podsumowań i do obwiniania aniżeli do refleksji umysły tracą przy tym swoją część historii i pozwalają sobie na upatrywanie w tym procesie efektu jakiejś diabelskiej istoty, obiecanej od początku istnienia świata jako tej, którą uznaje się za szczyt zła, a którą zwie się Państwem.

Jak to możliwe, że Państwo wiedzy, jest rzeczywiście oparte na wiedzy, jeśli weźmie się pod uwagę głoszone przez nie programy w dziedzinie polityki międzynarodowej, ekonomicznej i militarnej, a także w sprawach polityki wewnętrznej, jeśli spojrzy się na jego sposoby rozumienia i prowadzenia rządów zaufania, którego udziela ono licznym instytucjom obrachunkowym, jakimi się otacza, wydaje się ich być w rezultacie mało, zwłaszcza że ich działanie jest mało spójne, raz przesadnie rozwlekłe, raz niekompletne, jeśli przyjrzeć się rezultatom, jakie to Państwo otrzymuje? I załóżmy - ponieważ jest to perspektywa powszechnie dziś przyjęta - że jest dwóch aktorów lub dwa rodzaje danych w grze: Państwo rozumiane jako władza zwierzchnia i scentralizowana pod względem prawnym, sprawujące swą władzę na terytoriach i wobec populacji ściśle określonych, i Wiedza rozumiana jako ta, która realizowała się w postaci różnych instytucji mających na celu poznanie praw natury i która za pośrednictwem tych środków oznacza techniczne opanowanie licznych sektorów i poziomów rzeczywistości fizycznej oraz społecznej. Możliwe są liczne hipotezy. Przyjrzyjmy się tym, nad którymi obecnie trwa debata wśród doktrynerów.

W przypadku pierwszej hipotezy odpowiedzialność za tę sprzeczną sytuację trzeba by przypisać Wiedzy i jej niewystarczalności. Ale ta druga może być rozumiana dwojako. Można ją uznać za przypadkową lub też tymczasową. W optyce takiej za porażki lub też wady programów opartych na chęci panowania nad rzeczywistością odpowiadałyby nie projekty, ale ich ograniczony rozwój, biorąc pod uwagę możliwości powiększania się i przenikania oraz ich fragmentaryczny 
charakter. W optyce takiej to, co może pozostać jako zaburzenie lub cierpienie w zarządzaniu ludźmi, wywodzi się z faktu, iż nie wie się jeszcze wystarczająco dużo na temat tego, że nie panuje się skutecznie nad przejściem wiedzy do techniki, która ją aktualizuje, oraz tego, że koordynacji dyscyplin i praktyk brakuje doniosłości i dokładności... Tę pieśń śpiewa się zarówno na Wschodzie, jak i na Zachodzie. Poza przemysłem oraz wszystkim, co z góry pozwala na jego nieograniczony wzrost, nie ma zbawienia, szczęścia ani wolności. I przy okazji różnej retoryki powraca dyskusja mająca na celu wyjaśnienie, iż bieżące braki stanowią niezbędny etap trudnej drogi, która musi doprowadzić do świetlistego Miasta.

Przeciwko tym postępowym deklaracjom, stanowiącym częściej lub rzadziej powtarzane przez współczesną politykę credo, począwszy od XIX wieku, powstała pewna tradycja, która obnaża zasadniczą nieskuteczność projektu naukowego. Od czasu Sørena Kierkegaarda skarżącego się na terror stosowany przez filozofię historii w koncepcji Georga W. F. Hegla na temat subiektywnych głębin aż do chrześcijańskich marksologów gotowych zgodzić się we wszystkim z marksizmem Andrieja Żdanowa, byleby tylko uznał on swoją niezdolność myślenia poważnie o śmierci, przywołując Henriego Bergsona, który przez całe swoje życie pochylał się nad odkrywaniem zakątków rzeczywistości, która umknęła władzy fizyka, i który domagał się od naszej cywilizacji „uzupełnienia duszy”, której jej brakuje, powodów do oskarżania Wiedzy jest wiele. Nie jest pewne, czy taka postawa jest tak polemiczna, jakby się mogło wydawać. Powrócimy pokrótce do tego zagadnienia.

Druga hipoteza podkreśla złą wolę Państwa w tej kwestii. Ta zła wola obciąża nie tylko zwykły przyrost wiedzy, ale także jej oddziaływanie osiągające pełną wydajność w siłach wytwórczych. Jest to argumentacja marksistowska (która pochodzi z czasów Marksa i Engelsa) - mieszczańskie Państwo, w całości oddane kapitalizmowi, wspiera tylko tę wiedzę naukową, która może posłużyć korzyści posiadaczy, bojkotuje natomiast wolny rozwój sił wytwórczych, utrzymując represyjne stosunki produkcji, trwoni zasoby gospodarcze w niechlubnych wojnach, wykorzystuje wielkie odkrycia, ażeby wzmocnić swoją egoistyczną władzę. Idea ta jest do tego stopnia zakorzeniona, że Marks w jednym ze swoich rzadkich tekstów „wybiegających w przyszłość” wyobrażał sobie, że w bardzo krótkim czasie uspołecznienie środków produkcji spowodowałoby znaczny wzrost wydajności pracy, między innymi poprzez wykorzystanie w petni badań naukowych. Lenin mógł sądzić przez jakiś czas, że organizację naukową pracy propagowaną przez Fredericka W. Taylora można by wykorzystać z powodzeniem w radzieckim społeczeństwie i wzmocnić w ten sposób możliwości proletariatu (stalinizmowi nie udało się zrealizować tego pomysłu). Ale z punktu widzenia liberalizmu sprawa nie wygląda lepiej. Można się zastanawiać na przykład, czy istota krytyki, którą Raymond Aron kieruje pod adresem radzieckiego socjalizmu, nie następuje w istocie rzeczy tylko po tym, jak udaje się 
zapewnić „start” gospodarczy Związku Radzieckiego za pomocą surowego rządzenia. Nie zrozumiał on, że dyktatorskie planowanie, przytłaczająca ideologia, totalitaryzm miażdżący każdą indywidualną inicjatywę były wtedy hamulcem dla rozwoju sił wytwórczych na jednym z najbogatszych i największych terytoriów globu. Oczywiście te dwie argumentacje podtrzymywane przez głosicieli i intelektualistów panujących rządów należą do gatunku „obalonego" - do propagandy skierowanej w stronę „światowej opinii publicznej” — i mają na celu dowieść, że Państwo zasadniczo nie może wykazywać złej woli w stosunku do Wiedzy: jest to Państwo przeciwnika, rywala - Państwo nieukończone, odwrócone od swojego prawdziwego celu: bez przerwy zwiększanego bezpieczeństwa oraz szczęścia obywatelskiego, wadliwe Państwo, które pomija zasadniczy związek istniejący dziś pomiędzy sprawowaniem władzy centralnej a używaniem sprzętu naukowo-technicznego. Jedno i drugie rozumowanie, „marksistowskie” oraz pozytywistyczne, opierają się na idei, według której współczesne Państwo jest z natury Państwem wiedzy.

Istnieje inny sposób usprawiedliwienia niewydolności Państwa w tej kwestii, tym razem w odniesieniu do użytku wewnętrznego. Klasa polityczna chętnie daje do zrozumienia — głównie, jeśli chodzi o liberalne systemy - iż musi ona modulować, zmniejszać lub też ukrywać chęć naukowego prowadzenia aktywności politycznej, ażeby brać pod uwagę wrażliwość narodu, który reprezentuje, co wiąże się z ryzykiem świadomości narodu, że jest przedmiotem technicznej manipulacji. Tak samo powinno się przystąpić w sposób umiarkowany do stosowania technologii politycznej, a w każdym razie do ozdabiania jej kolorami humanizmu². Innym czynnikiem przyczyniającym się do stałego hamowania rozwoju administracji naukowej i do wprowadzania rozbieżności jest irracjonalność światowego układu sił, zagrożenia wojną, nierówna wiedza, jaką dysponują różne rządy na temat Państwa. Taka sytuacja powoduje kryzysy polityczno-ekonomiczne, które zmuszają do natychmiastowego przeciwdziałania zbliżającym się niebezpieczeństwom oraz do zmiany najlepiej opracowanych planów. W każdym razie, gdyby nie istniał naród (i jego niewiedza), a także konflikty sił (i ryzyko wojny), gdyby nie było tego, dla czego powołuje się rządzących według tradycji klasycznej, sojusz Państwa i Rozumu, opatrzności i Wiedzy byłby przesądzony.

Należy zauważyć, że to różnorodne rozumowanie, bez względu na to, czy wiąże się z odpowiedzialnością za sprzeczności, z obciążeniami oraz z niedociągnięciami rządowej polityki w związku z nieudolnością rozwoju naukowego lub też niezdolnością Państwa, ma tę wspólną cechę, że walczy o Państwo ba rd zi ej uczone i o wiedzę bardziej państwową. Tak, jak dotyczy to ujęcia uogólnionego

\footnotetext{
${ }^{2}$ Czyż nie jest marksistą Louis Althusser, który tłumaczył, że partia, posiadacz Wiedzy, nie mogła nie prezentować i d e ologi c z n i e swojego programu, ponieważ z natury społeczeństwo myśli w kategoriach ideologicznych?
} 
progresywizmu, obecna sytuacja określona jest jako okres przejściowy. Jeśli chodzi o stanowisko tych, którzy domagają się „uzupełnienia duszy”, kiedy nie nasila się ono w dyskursach apokaliptycznych głoszących nieodwracalny upadek cywilizacji lub bezwzględną nędzę każdej społeczności, powraca wreszcie, ażeby domagać się zrobienia miejsca i powierzenia funkcji duszpasterzom odpowiedzialnym za przypominanie Władcy, że myliłby się, gdyby kazał tłumić swoje pozytywne uczucia.

Im więcej Wiedzy, tym więcej Państwa! Czy to hasło będzie postrzegane jako określające jakieś rozwiązanie i program, czy też będzie przedstawione jako stwierdzenie nieuchronności, to pojawia się ono jako zwykła konkluzja sformułowanego przed momentem wyjaśnienia. Konkluzja taka odpowiada w znacznym stopniu ucieczce naprzód, którą podejmuje polityka rządowa, która, ażeby odpowiedzieć na kryzysy atakujące światowy system, nie znajduje innych odpowiedzi, jak tylko mnożenie powstawania instytucji prawodawczych oraz kompetentnych komisji, wzmacnianie sieci i kontroli do tego stopnia, iż ma się prawo zadać pytanie, czy podobne rozumowanie nie jest po prostu przedłużeniem debaty o tej samej polityce. Równie dobrze, jeśli chcemy się uwolnić od tej propagandy, rozsądne jest zastanowienie się nad nieco uproszczonym charakterem powstałego problemu. Jeśli istniałby ciągły niepokój i potwierdzona ambicja rządzących współczesnymi Państwami, aby myśleć i działać w sposób naukowy, jeśli to retoryka polityczna w potyczkach międzynarodowych, podobnie jak w walkach o władzę państwową, uznałaby za wartościowe zasady postępu, szczęścia, jak i bezpieczeństwa, jeśli to organy publiczne mające dominację i sprawujące kontrolę nad rzeczywistością społeczną mnożyłyby się, to nie oznacza w żadnym razie, że można by się zadowolić, zdając sobie sprawę z takiej sytuacji, odniesieniem się do zasady Państwa wiedzy, które byłoby sumowaniem lub prostą koniunkcją dwu przypuszczalnie prostych i jednolitych rzeczywistości. Nie wystarczy nawet przywołanie jakiegokolwiek „dookreślenia” jednej rzeczywistości przez drugą. Tak naprawdę, zarówno w tym przypadku, jak i w wielu innych, należy zbadać dane historyczne oraz zgodzić się na komplikowanie koncepcji.

Odłóżmy w tym miejscu pytanie o definicję Państwa. Zauważmy jedynie, że dziś, począwszy od dziennikarstwa aż po teorię polityczną, i to niezależnie od głoszonej doktryny, utrzymywana jest wokół tego pojęcia dokuczliwa mroczność. Przedmiotem wszystkich tych antagonizmów i wszelkiej żądzy, „Rozumu w działaniu” lub „wszystkich nieczułych potworów, najbardziej nieczułego”, jakie stanowi Państwo, jest — zarazem i w nierozerwalnym połączeniu nadrzędna zasada, wynikającą z niej przestrzeń sądowo-prawna, rząd, który ją uosabia, całość władzy publicznej i aparatów Państwa, własność klasy dominującej, miejsce, gdzie równoważą się siły społeczne narodu oraz wiele innych rzeczy. Zrozumiałe jest, że Michel Foucault odwrócił się od tej hybrydowej transcendencji i wolał rozpocząć sprawowanie władzy tam, gdzie można zbadać 
jej rzeczywiste mechanizmy. Przybliżmy raczej inną część pytania i zapytajmy się, co kryje określenie „Wiedza” połączone z Pańs t we m i co może oznaczać ta Wiedza przywoływana tak często. Problem jest tak samo złożony jak ten odnoszący się do definicji współczesnego Lewiatana. I będziemy musieli, również w tym względzie, zadowolić się kilkoma wstępnymi informacjami, nie tylko z uwagi na brak miejsca, ale przede wszystkim z uwagi na brak szczegółowych badań.

Pierwsza grupa uwag dotyczy pewnego uproszczenia, na którym opiera się bieżąca wiedza polityczna. Według jednej z zuchwałych wizji, tak bardzo cenionych, czy to przez nowy akademizm „marksistowski”, czy to przez jego przeciwników, powstałby jednolity prąd racjonalistyczny, który przemierzałby historię i wyjaśniał naszą sytuację (obiecującą, według jednych, a odpychającą, według drugich). Rozpoczęłoby się to od Platona, utrzymywałoby się wraz z Kartezjuszem, który chciał „uczynić człowieka panem i posiadaczem przyrody” — i wraz z filozofami epoki oświecenia, którzy wdrożyli tę myśl i nadali jej wymiar polityczny, znalazłoby w dziele Heglowskim swoją najbardziej wypracowaną wymowę, ale jeszcze odbiegającą od swojego znaczenia; znaczenia, które uaktualniłoby się dzięki Marksowi i marksizmowi mającymi przywilej wprowadzenia do rzeczywistości społecznej w całym jej tworzeniu się tego słynnego planu całkowitej, racjonalnej determinacji. Nie rozpoczynajmy dyskusji dotyczącej śmiesznej i linearnej interpretacji myśli takich, jak myśli Platona, Kartezjusza i myśl epoki Aufklärung. Podkreślmy tylko, że zbyt pospiesznie jest zestawić pod tym samym znaczeniem Wiedzę postrzeganą przez Hegla i działalność naukową w rozumieniu pozytywistów w drugiej połowie XIX wieku. Oznaczałoby to niezdolność pojmowania krytyki, której dokonuje Marks w odniesieniu do polityki Hegla (i w konsekwencji zupełne przeciwstawienie się nowemu punktowi widzenia, marksizmowi Marksa w stosunku do filozofii spekulatywnej), oraz niezdolność uwolnienia założeń od nieszczęśliwego odkrycia przez Engelsa filozofii materializmu historycznego. Oznacza to również rezygnację z rozumienia czegokolwiek z korzystnego dla grup utrzymujących się przy władzy statusu instytucji naukowych.

Kiedy Hegel określa Państwo jako Rozum w działaniu, kiedy przedstawia on Wissenschaft der Logik jako Wiedzę absolutną, umieszcza siebie w perspektywie klasycznej metafizyki i jej eschatologii. Przeciwko filozofii rozumu ludzkiego - filozofii Kanta, ale również Encyklopedystów oraz wiedzy eksperymentalnej w stadium powstawania, stara się on przywrócić suwerenne prawa rozumu teoretycznego. Chodzi mu w tej kwestii o obalenie wszelkich roszczeń potwierdzonych przez częściowe „elementy” Umysłu: Sztukę, Religię, jak również nauki w kierowaniu losem ludzkości. Jedynie narody (i ich bohaterowie) tworzą historię; jedynie Rozum filozoficzny zdolny jest pojąć tę historię oraz pokazać, w jaki sposób musi być ona poznana. Wszelki woluntaryzm jest wykluczony z teorii politycznej Hegla: Zasady filozofii Prawa mają jedyny cel poznania wiedzy fundamentalnej. Jest również anachronizmem rozumienie 
Państwa konstytucyjnego i administracyjnego opisanego w tekście z 1821 roku jako tego, które stanowi ilustrację „grup militarno-przemysłowych” panujących dziś w Stanach Zjednoczonych i w Związku Radzieckim. Hegel bada dokładnie obowiązek, któremu poddana jest współczesna suwerenność, polegający na ucieleśnianiu się na zewnątrz $\mathrm{w}$ postaci silnej armii dążącej do światowej dominacji, a wewnątrz - w postaci licznej i kompetentnej administracji, która decyduje ostatecznie o interesie ogólnym. Postrzega on w sposób jasny charakter ściśle zmilitaryzowany i biurokratyczny organizacji państwowej. Odrzuca jednak ideę głoszącą, że czynniki ekonomiczne mogą być dominujące i że polityk musi ustąpić lub też wkomponować się w jakąkolwiek wiedzę empiryczną, ekonomię polityczną lub też wiedzę społeczeństwa; albo też, że ma ona zdawać sobie sprawę z konieczności narzuconych przez podbój natury empirycznej. Ujmując rzeczy pokrótce, przemysł, a jeszcze bardziej ogólnie wytwarzanie dóbr wiąże się $\mathrm{w}$ tej perspektywie z problemem zarządzania.

W tym miejscu mamy do czynienia $\mathrm{z}$ jedn ą $\mathrm{z}$ rozbieżności pomiędzy filozofią spekulatywną a nową analizą Marksa. Jeśli wierzyć pierwszym stronom Ideologii niemieckiej, a nic nie pozwala stwierdzić, że Marks kiedykolwiek zrezygnował z poglądów tam przedstawionych, to jedyną przesłanką tej analizy jest ta dotycząca człowieka empirycznego. To oznacza, że w przeciwieństwie do Hegla, ta analiza obiera sobie za cel poznanie nie tyle rzeczywistości Państwa, ile istnienia społeczeństwa jako tego, które tworzone jest i przetwarzane przez zbiorowe praktyki; i że ma ona badać warunki, w jakich wykonuje się pracę, przez co społeczeństwo istnieje oraz rozwija się, a to z punktu widzenia tych, którzy pracują. Znane są konsekwencje tego założenia; zarówno wprowadzenia teorii rewolucji politycznych, krytyki ekonomii politycznej, tworzenia zgromadzenia skupiającego walczących proletariuszy, jak i powołania innej dogmatyzacji w formie globalnej koncepcji świata i filozofii historii. Dodajmy tymczasem ważną dygresję: zarzuca się dziś chętnie Marksowi, zwłaszcza wśród jego najbardziej ortodoksyjnych zwolenników, pominięcie opracowania teorii państwowej, pozwalając w ten sposób, poprzez jego milczenie, na te wszystkie dewiacje, błędy lub zbrodnie (ortodoksja „uwolniona” jest na dobrej drodze przyznania tych zróżnicowanych gradacji), o które obwiniano zaraz potem Państwo socjalistyczne. Pozostawmy (udawaną) naiwność argumentu w jego aspekcie politycznym - represję w Kronsztadzie i dekulakizację mające źródło między wierszami w tekście Marksa! - ażeby podtrzymać jedynie przesłanie teoretyczne. Zarzut ten przypomina zarzut kierowany pod adresem Kartezjusza, iż nie zbudował ostatecznej moralności opartej na metodzie oczywistości. Jeśli Kartezjusz nie napisał Traktatu o moralności, to dlatego, że uważał to jednocześnie i za zbyteczne, i za niestosowne. Tłumaczy się z tego i zadowala się napisaniem Traktatu o namiętnościach duszy, sądząc, iż w odniesieniu do struktury „o najwyższej i najdoskonalszej moralności” trzeba poczekać, aż wiedza będzie prawie ukończona. W ten sam sposób Marks jasno tłumaczy swoje 
„zaniechanie” w Krytyce Programu Gotajskiego, twierdząc, że wystarczyło stworzyć Międzynarodówkę robotniczą oraz opublikować Księgę I Kapitatu. Cesare Luporini ${ }^{3}$ pokazuje bardzo trafnie, że w optyce Marksa samoorganizacja społeczeństwa tych, którzy je tworzą, czyni zbędną wszelką spekulację na temat typu Państwa odpowiadającego objęciu władzy przez „proletariat w zbrö”. To dlatego ukazuje on jako głupotę lub też jako reakcyjne manipulacje wariacje na temat „niemieckiego Państwa robotniczego” dokonane przez socjalistów zgromadzonych w Gotha w 1875 roku.

Kartezjusz pozostawał w sferze marzeń, kiedy sądził, że opanowanie Wiedzy jest bliskie! Marks pozostawał w sferze marzeń, kiedy spodziewał się, że uspołecznienie środków produkcji doprowadzi do transformacji przemysłu takiego, w którym przeszłoby się łatwo i w krótkim czasie od rządzenia ludźmi do administrowania rzeczami! Jeden i drugi sądzili, każdy w ujęciu wiedzy swojej epoki, że opanowanie ideowe i materialne rzeczywistości przyniesie rozwiązanie problemów, które nurtują byt indywidualny i społeczny, oraz pozwoli znieść arbitralność moralności, przypadkowość polityczną, sztuczny porządek Państwa; tak jak Lenin sądzit, że naukowa organizacja pracy, nadzorowana w sposób proletariacki doprowadzi produkcję socjalistyczną do zrobienia kroku naprzód, tak jak wyobraził on sobie, że lokomotywy rozwiązałyby trudy wojny i zaopatrzenia i że „sowieci + elektryczność” doprowadziliby do upadku Państwa...

Przeświadczenie to, ta nowa pobożność wymagały dokładniej, z jednej strony, istnienia właściwej władzy zdolnej do obalenia się i, z drugiej — to, co nas tutaj interesuje - istnienia Wiedzy jako mathesis universalis, mawiał Kartezjusz, jako ko rpus u ustrukturyzowanego i jednorodnego, jako wiedzy jednolitej definiującej dokładnie swoje cele, potrafiącej zdominować je ideowo, a także uczynić je w całości transparentnymi, oraz definiującej w ten sposób techniki transformacji rzeczywistości bez niespodzianek. Krótko mówiąc, żeby Wiedza wraz ze swoim matematycznym językiem oraz złożonymi narzędziami badawczymi realizowała wreszcie ideał racjonalnego dyskursu tak, jak to planowali metafizycy. To tutaj odnajdujemy tę drugą grupę uwag, które, mówiąc w skrócie, chcielibyśmy poczynić w tym miejscu: są to tylko wskazówki i dotyczą one ideowego statutu badań naukowych. Od ich rozwoju w XIX wieku korpus wiedzy przyrodniczej - w tym paragrafie mowa jest tylko o nim — przeszedł przez pewne napięcie: z jednej strony pojawia się chęć prowadzenia badań „we wszystkich kierunkach”, które gromadzą poznanie i w małym stopniu zajmując się metodologią ogólną, nie przestają zderzać się w miarę swojego rozwoju z nową rzeczywistością. Tendencja ta teoretyzuje tylko w granicach teorii niezbędnej do ich zgłębiania i uwzględnia zastosowania techniczne zdobytych rezultatów jako naturalną konsekwencję, a nie wymóg. $\mathrm{Z}$ drugiej strony zaś pojawia się chęć

\footnotetext{
${ }^{3}$ Wystąpienie w Centrum Badań o Heglu i Marksie w Poitiers w grudniu 1977 roku.
} 
filozoficzna gromadzenia informacji w formie Wiedzy dokładnie opisującej to, co jest, chęć dążenia za pomocą tego tak mocnego narzędzia, jakim jest stary plan Wiedzy absolutnej, któremu przyświeca idea, że prowizoryczne wypowiedzi, jakimi są wypowiedzi potwierdzone naukowo, łączą się z wypowiedziami, jakie dopiero pojawią się w przyszłości, że każdy naturalny fakt w całej swej kompleksowości zostaje sprowadzony do skomplikowanego, ale ujednoliconego porządku. Nie jest pewne, czy napięcie owo nie będzie przyrodzone naturze badawczej i czy nie będzie jej szkodzić. To, co jest natomiast stwierdzone, to fakt, że bardzo często zwolennicy Wiedzy (wielka litera nie jest tu przypadkowa) oraz ci, którzy tak jak Nietzsche, skrytykowali ich, podkreślili jedynie drugi aspekt, przyczyniając się w znacznym stopniu do ułatwienia działania władzy, której różne postaci zostały omówione powyżej.

To właśnie do takiego postrzegania przeniknęła myśl, że istnieje ciągłość wywodząca się z koncepcji Rozumu filozoficznego i podążająca w kierunku koncepcji Rozumu naukowego. Ten drugi wprowadzony jest w sposób praktyczny lub materialistyczny przez ten pierwszy. Doprowadza to do sytuacji, że istnieje dziś pewien rodzaj możliwej ontologii eksperymentalnej, której skrajności, spirytualistyczną i materialistyczną, reprezentują dziś Teilhard de Chardin oraz Żdanow. Okazuje się zatem, obserwując obecny rozwój, że aby nie skompromitować niczego w postępie wiedzy, pojęcie Wiedzy ujednoliconej zaczyna się rozdzielać. Ponadto dziedziny badawcze mnożą się bez możliwości i chęci kierowania nimi, „odnoszenie się do modelu” musi być ostrożne, nowe „cele” wynurzają się z każdej strony, począwszy od fizyki subatomowej, a skończywszy na astrofizyce, przechodząc przez mikrobiologię; postęp narzędzi do obserwacji ujawnia charakter niespodziewanej różnorodności, a część „genialnego majsterkowania”, na którym polegają badania naukowe, pozostaje tak mocna jedynie dzięki przeszłości. „Kontynent przyrodniczy” jest konstelacją pojedynczych regionów wymagających specyficznych procesów rozumowania. $\mathrm{Z}$ pewnością słuszne jest pokładanie nadziei w końcowym zjednoczeniu, ale przebiega to tak samo, jak wiara w zmartwychwstanie ciała.

Od tego momentu, póki co, przy badaniu praktyk za abstrakcyjne uchodzi przywoływanie W i e d zy. Wiedza to tylko obraz lub też wyraz maskujący bardzo różne realia. Należy również zastanowić się, przywołując porozumienie Państwa i Wiedzy, o jakiej wiedzy, o jakich celach, o jakich miejscach, a także o jakich instytucjach jest mowa. Tym samym, kiedy podkreśla się odpowiedzialność Wiedzy i jej technicznej dominacji w stosunku do rzeczywistość przyrodniczej i społecznej, należy się zastanowić nad faktycznym stosunkiem istniejącym pomiędzy przywołaną dziedziną wiedzy a działającym przedsięwzięciem technicznym. Dlatego, że właściwością władzy technokratycznej jest pretendowanie do bycia mądrą oraz do korzystania ze swoich przywilejów i kapitału w różnych umysłach po to, aby stworzyć maszyny w miarę dobrze działające bez jasnej wiedzy na temat tego, jakie siły zostały przy tym użyte. Nie ma co narzekać, że 
technokraci wiedzą o tym aż nadto: znają to zbyt dobrze, żeby mogli to zignorować.

Ta ostatnia uwaga pozwala przejść do trzeciego zbioru wskazówek, czym chcielibyśmy zakończyć nasze rozważanie. Podwójny ruch, który uczynił badania naukowe jeszcze bardziej narażonymi na ingerencję działania władzy, powstał w XX wieku. Z jednej strony ogromny rozwój w dziedzinie fizyki, chemii i biologii tłumaczony był coraz silniejszym wymogiem: znacznym wzrostem urządzenia doświadczalnego oraz koniecznością pracy zbiorowej. Laboratorium stało się samo w sobie rodzajem manufaktury. Nie chodzi już o badanie w pojedynkę; tradycyjne ramy akademickie już tu nie wystarczą. Potrzebne są bardzo ważne środki oraz kierownictwo, które ustala priorytety i które planuje. Bez względu na formę badań perspektywa opłacalności bierze górę. Przejście do zastosowania oraz technicznego wdrożenia nie stanowi już nagrody czy też dodatkowego dowodu ważności: jest ono od tej pory niezbędne.

W tej samej chwili, od pierwszej wojny światowej, międzynarodowe konflikty przyjmują taki zasięg, że narody są w nie całkowicie zaangażowane. Wojna totalna, nacjonalizmy lub totalitarne ideologie mobilizują wszystkich obywateli, a zwłaszcza uczonych, których udział w sile przemysłowej i militarnej jest decydujący. W pewien sposób totalna wojna oraz zbrojny pokój tworzą sytuację sprzyjającą rozwojowi badań: przydatność sektorów z pozoru nieopłacalnych lub mało opłacalnych może zostać wreszcie uznana. Jeśli do tych aspektów ściśle militarnych doda się rywalizację ekonomiczną przeciwstawiającą jedne grupy kapitałowe drugim, w podboju rynków i bloków zwanych ideologicznymi w dążeniu do pozycji światowego lidera oraz w sytuacji okradania Trzeciego Świata, to zauważa się, że badania naukowe, niezbędne do produkcji nowych "dóbr" i niebywałych przedsięwzięć, zyskują teraz w walce o władzę.

Otóż ten pierwszy fakt ogłoszony w XIX wieku przez Marksa i Herberta Spencera posiada moc indukcyjną. Tak samo jak nauki nazywane dziś humanistycznymi zaczęły się rozwijać od roku 1850 na wzór nauk fizycznych i biologicznych, których powodzenie stawało się oczywiste, również przy okazji światowych i międzynarodowych wojen, kryzysów ekonomicznych, międzynarodowych konfliktów zbrojnych nauki humanistyczne pozwolity sobie coraz chętniej naśladować zmiany, przez które przechodziły nauki przyrodnicze. Zinstytucjonalizowaty się one w obrębie sektorów prywatnego i publicznego; przyjęły z zadowoleniem schematy czytelności zaproponowane przez Jamesa Burnhama dla przyszłego świata. Uśmiechały się ironicznie do pesymistycznych przepowiedni Aldousa Huxleya, marząc o rozwoju narzędzi. Wyposażyły się też i "połączyły”; ażeby wzmocnić swoją pozycję społeczną, brały udział w podaży i oferowały usługi, najpierw w krytycznych okresach i w pilnych przypadkach, a później w codziennej pospolitości. Zdarzyło się, że nauki świadczyły usługi!

Mimetyzm ten, szeroko uproszczony przez kontekst polityczny i często propagowany przez sprawujące władzę rządy, doszedł aż do stworzenia złożonego 
obrazu, w którym spotykają się zazębiające się gatunki i cechy charakterystyczne schematu, który prezentuje się w sposób szkolny w odniesieniu do fizyki. Istniałaby zatem na przykład socjologia ogólna; oczywiste jest, że stosujemy tutaj terminologię uproszczoną, durkheimowsko-weberowską, którą daje się łatwo przenieść do słownictwa używanego w radzieckim „obozie” marksistowskim. Tutaj socjologia ogólna oznacza materializm historyczny ogólnie rzecz biorąc, który określałby się i znajdowałby zastosowanie według swoich „celów empirycznych" w socjologii religijnej, wyborczej, miejskiej, wiejskiej, kolonialnej itd. lub też według „celów abstrakcyjnych” związanych z pokrewnymi dyscyplinami, w socjologii sądowej, ekonomicznej, artystycznej, poznawczej itd., albo jeszcze według swoich „metod”, to jest w odniesieniu do matematycznego opracowania mniej lub bardziej wyrafinowanego, któremu socjologia podporządkowuje swoje treści.

W ten sposób zrodził się korpus nauk humanistycznych, wyścig szczurów lub też miejsce cichej rywalizacji, centrum badań w zakresie reklamy lub też smutne biurokracje jak ta, którą opisuje Świetlana przyszłość Aleksandra Zinowiewa. Byłoby absurdem przyznać, że cała ta zgromadzona wiedza jest przedawniona i okryta nie wiadomo jaką hańbą. Jest to wiedza rzeczywista w odniesieniu do niektórych dziedzin — i prawdopodobnie dla wielu która w swojej dysproporcji posiada efekt zrozumiałości i pozwala lepiej się orientować w funkcjonowaniu naszych społeczeństw. To, co jest bezprawne, to twierdzenie, że takie doktrynalne ukierunkowanie, sporządzone w ko r pu sie, posiada efekt jasności globalnej tak, jak godne pochwały jest wyciąganie z tego technik zmiany społeczeństwa opartych na prawdzie. Cały fałszywy mechanizm władzy technokratycznej tkwi w tym, że zakłada ona istnienie Wiedzy powstałej gdzie indziej: w uniwersytetach, instytucjach badawczych. Zna ona ich podstawowe zasady oraz wyniki i zobowiązuje się zastosować je w danej szczególnej sytuacji tak, ażeby osiągnąć cele, które sobie ustaliła w zależności od tego, co wie. Istnieją z pewnością uniwersytety, instytucje badawcze, w których rozwija się wszelaka wiedza, z której jedna jest słaba, a druga mocna i trwała. Ale ta Wiedza nie istnieje. Co do organów technokratycznych korzystających z powierzonego im przez porządek publiczny, którego są one częścią, autorytetu, ich kompetencje polegające na manipulowaniu tekstami i cyframi, dobrą informacją, którą dysponują, oraz umiejętnościami na wysokim poziomie służą opracowaniu programów interwencyjnych uzyskujących status zarządzenia i oddziałujących rzeczywiście na społeczeństwo, ale niekoniecznie osiągających wyznaczony cel.

Mówiąc jak filozof, połączenie pomiędzy wiedzą nazywaną zasadną, wymogami tego programu a skutkami wynikającymi z zastosowania tego programu nie jest w żaden sposób konieczne. Wiedza ta wpisuje się w przynajmniej dwie przypadkowe alternatywy. Przy czym oczywiste jest, że przypadkowi nie zależy ani na tymczasowej niewystarczalności wiedzy, ani też na niekompetencji lub 
złośliwości technokraty, ani na złej naturze społeczeństwa. Można z pewnością dalej marzyć o „całkowitej determinacji” i wyobrażać sobie, że wyższa wiedza dysponująca metajęzykiem technologii będzie zdolna kalkulować, a zatem zmniejszyć ten przypadek; lub też że polityka będzie wystarczająco klarowna i stanowcza tak, aby jej cele wypełniły się bez szeroko zakrojonych przygotowań. Ale, mówiąc dokładnie, należy się zastanowić, czy te pomysły o „całkowitej determinacji”, o „transparentnym społeczeństwie”, o absolutnej znajomości warunków nie są powiązane $\mathrm{z}$ tego samego powodu, co w przypadku Suwerenności, która odegra kluczową rolę w działaniu władzy prowadzącej w XVII i XVIII wieku do instytucji na kształt Państwa, jako obowiązkowych ram narodowej „rzeczywistości" - do dziedzictwa teologicznego. Jak o tym przypomina Leo Strauss, pomysłów, o których mowa, brakuje w mądrości antycznej. Nie pasują one do żadnej konieczności ideowej ani historycznej. Powstałe kiedyś dla pewnych celów, reaktywowane w innym, celem legitymizacji jakiegoś określonego typu władzy, tej, która sprawuje rządy w Państwie narodowym, służą one dziś, reaktywowane w inny sposób, stworzeniu tego wizerunku Państwa wiedzy, nad funkcjonowaniem którego zastanawialiśmy się na początku tego szkicu.

$\mathrm{Z}$ tego zróżnicowanego nazewnictwa - niekompletnego w tym podwójnym znaczeniu, że brakuje mu rozwinięcia i przede wszystkim uzasadnienia i że zostało zawieszone pytanie o istotę Państwa - czyż nie wynika z tego, że pojęcie „Państwa wiedzy” musi być odrzucone jako nieadekwatne? Odpowiedź byłaby oczywiście twierdząca, gdybyśmy wykorzystywali to wyrażenie dla określenia jakiejś pojedynczej formacji politycznej następującej w porządku historycznym typu heglowskiego po Państwie narodowym oraz zastępującej go dialektycznie na scenie przemiany społecznej. Wszystko to prowadzi w efekcie do pokazania, że Państwo nie jest Państwe m wiedzy w tym sensie, że gdyby rządzący stali się naukowcami lub też naukowcy stali się rządzącymi, to polityka i Wiedza byłyby na drodze do scalenia się. Jedyne istniejące trudności tkwiłyby bądź w niewiedzy dobrowolnej lub niezamierzonej niektórych rządzących, bądź też w tymczasowym nieukończeniu Wiedzy, bądź w sprzeciwie ze strony społeczeństw źle poinformowanych, nękanych pasjami i archaicznością, bądź też wreszcie w połączeniu tych trzech czynników. Można czasami usiłować, ze strony technokratycznej, głosić śmierć ideologii lub jej żądać, a ze strony sprzymierzeńców duchowości, ogłosić przyszłe zwycięstwo Nauki nieludzkiej. Żaden "postęp" nie został osiągnięty i nie występuje, podążając w kierunku spełnienia starego ideału racjonalizacji porządku publicznego ani wprowadzając zarządzanie społeczeństwami oparte na nowym ideale obserwacji, eksperymentowania i kalkulacji.

To, co zostało wprowadzone i rośnie w siłę, to technika władzy, która chełpi się racjonalnością celem zapewnienia swojej legitymizacji i propagandy i która stworzyła przede wszystkim instytucje zwane technokratycznymi, wykorzystujące wiedzę przekazaną w wyniku badań naukowych (ale także ukierunkowującą 
te badania) po to, ażeby pomnożyć swoje środki materialne ingerencji i dominacji społeczeństw, nad którymi ta władza sprawuje rządy. Tak naprawdę nic się nie zmieniło od XIX wieku oprócz tego, że Kapitał i podstawowy sposób organizacji wspólnotowej, który on implikuje powiększył swoją sieć na całym świecie, i że żaden sektor mu się już nie wymknie; że kształt Państwa jako formy polityczno-prawnej towarzyszący rozmieszczaniu się współczesnego kapitalizmu — „zglobalizował się” i że trzy Państwa narodowe założycielskie: Zjednoczone Królestwo, Francja i Stany Zjednoczone uczyniły wiele małych państw, z których niektóre stały się duże, a nawet bardzo duże. Te dwie stanowcze siły decydujące, przemysł i armia, zwiększyły jeszcze bardziej swoją przewagę i stanowią sposoby „międzynarodowe”, przy których trochę bledną religijne ekumenizmy i solidarność proletariacka.

Konfiguracja całości pozostała ta sama; niektóre wypukłości uwydatniły się. Państwo wiedzy odzwierciedla tę generującą zabójstwa i masowy terror sytuację. Musimy utrzymać tutaj pojęcie w zakresie, w jakim podkreśla ono fakt, że dziś polityczne organy rządowe, organy, które zobowiązały się do ucieleśniania suwerenności obok ciała prawodawczego i które są tradycyjnie odpowiedzialne za rządzenie, powiększyły w znaczny sposób, z różnych przyczyn, zakres swojej władzy. Znajduje się ona od tej pory w obrębie jego działania, bezpośrednio lub pośrednio, w coraz liczniejszych sektorach współistnienia społecznego, które do tej pory należały do „życia prywatnego” — do tego stopnia, że można się zastanawiać, czy de mokracja (ludowa lub liberalna) w swoim rzeczywistym użyciu oznacza nieingerowanie narodu w sprawy rządu, ale ingerowanie rządu w sprawy narodu. Względem odpowiedzialności, jaką organy te sobie przyznały, naśladując przy tym przykład dostarczany im przez armię i porządek gospodarczy, rozmnożyły się one w wyspecjalizowane podmioty, zdecydowane dostosować się w zadaniach zarządczych, to znaczy w wykonywaniu swojej władzy do modelu dostarczonego przez pracę naukową: definicja przedmiotu lub sektora - analiza, jeśli to możliwe, ilościowa tego drugiego — opracowanie programu interwencji - wdrożenie tego programu poprzez podwójny sposób skrupulatnych przepisów i poprzez stosowanie technik przetwarzania rzeczywistości wdrożonych przez naukę. Wynika z tego modelowanie społecznej rzeczywistości wzmacniającej i uzupełniającej model, który kieruje wzrostem przemysłowym, ale który, jeszcze dużo bardziej subtelnie i dokładnie, wyznacza drogę zachowania „użytkownikom” tras i zaułków, określając ich prędkość i powolność, poruszanie się, przerwy, ograniczenia oraz swobody. Rząd o takim charakterze, jak zwykło się to określać potocznie i błędnie Państwem, uważa się za u czony.

To, że nie wie za wiele, potwierdza aktualna sytuacja, zarówno światowa, jak i międzynarodowa! Ale ponoć jest w interesie politycznym, ażeby pokazać dokładnie mechanizmy ideowe i techniczne, które przewodniczą w sprawowaniu władzy tak często idiotycznej i krwawej. Dostrzeżono by, być może 
fakt, iż trzeba przestać rozmyślać, zakładając, że ci, którzy decydują: przywódcy polityczni, prezesi dużych przedsiębiorstw, szefowie wielkich laboratoriów, szare eminencje technokracji, bankierzy najwyższego szczebla, wszelkiej maści eksperci są „poniekąd”, jak to się lubi teraz określać, powiązani z tajnikami Wiedzy. Dostrzeżono by być może fakt, iż trzeba odciąć się raz nas zawsze od tej myśli, że istnieje jakaś Wiedza, lub też od tej, jeszcze bardziej zgubnej, że jest jakiś Autorytet, którego słowo byłoby z definicji Wiedzą. Jeśli władza jest wciąż naga i jeśli jej sprawowanie jest niczym innym jak tylko machinacją lub majsterkowaniem, to czyż może być ona jeszcze słabsza?

\section{Z jezyka francuskiego przetożyta Ewelina MITERA*}

* Dr nauk humanistycznych, adiunkt w Katedrze Glottodydaktyki i Nauczania Zdalnego Instytutu Neofilologii Uniwersytetu Pedagogicznego im. KEN w Krakowie, tłumacz języka francuskiego. E-mail: ewelina.mitera@up.krakow.pl. 